\title{
STUDI TERHADAP MOTIVASI BERPRESTASI TIM BOLA VOLI PUTRI KOTA CIREBON PADA PORDA TAHUN 2018
}

\author{
Devi Agustin', Rajip M Rusdiyanto² dan Ali Priyono ${ }^{3}$ \\ Universitas Majalengka, Indonesia \\ e-mail:devi3agustin@yahoo.co.id
}

\begin{abstract}
ABSTRAK. Tujuan penelitian ini untuk mengetahui faktor motivasi instrinsik atau motivasi ekstrinsik yang dominan dalam motivasi berprestasi tim bola voli putri kota Cirebon. Dari hasil observasi peneliti ditemukan bahwa motivasi yang terdapat dalam atlet bola voli putri kota Cirebon pada porda 2018 memiliki perbedaan yang ditinjau dari indikator motivasi instrinsik dan motivasi ekstrinsik. Metode penelitian adalah penelitian deskriptif kuantitatif. Sampel penelitian ini adalah atlet tim bola voli putrid porda kota Cirebon, dengan jumlah sampel 12 responden. Instrumen penelitian menggunakan kuesioner atau angket. Analisis data menggunakan deskriptif persentase. Hasil penelitian menunjukan rata-rata skor motivasi berprestasi tim bola voli putri Kota Cirebon adalah 95,08 dengan tingkat persentase sebesar 84\% dikatagorikan dalam klasifikasi sangat tinggi. Adapun motivasi berprestasi ini di pengaruhi beberapa indikator pendukung antara lain: rata-rata motivasi intrinsik adalah sebesar sebesar 46,83 dengan tingkat persentase sebesar $90 \%$, berdasarkan hasil yang diperoleh dan disimpulkan bahwa indikator motivasi intrinsik dikategorikan dalam klasifikasi "Sangat Tinggi". Adapun rata-rata indikator motivasi ekstrinsik adalah sebesar 48,25 dengan tingkat persentase sebesar $75 \%$, berdasarkan hasil yang diperoleh dan disimpulkan bahwa indikator motivasi ekstrinsik dikategorikan dalam klasifikasi "Tinggi". Dengan hasil tersebut bahwa motivasi berprestasi atlet tim bola voli kota Cirebon yang diperoleh dari 12 responden lebih dominan pada motivasi instrinsik, indikatornya meliputi pencapaian, stimulasi, dan pengetahuan.
\end{abstract}

Kata Kunci: Motivasi berprestasi; Bola voli

\section{Pendahuluan}

Bola voli Kota Cirebon berdiri pada tahun 2003 yang awalnya bernama Bima Putri, tim bola voli Kota Cirebon sudah pernah mengikuti sejumlah turnamen bola voli baik tingkat pelajar maupun daerah antara lain : juara 1 Popwil di Majalengka, juara 2 Popwil di Cirebon, juara 3 Popwil di Cirebon, masuk 4 besar pada Porda pada tahun 2014 di Bekasi dan yang baru saja dilaksanakan yaitu Porda yang dilaksankan pada bulan oktober 2018 di Bogor namun sangat disayangkan Kota Cirebon hanya sampai dibabak penyisihan. Bertolak dari kondisi yang ada, maka yang menjadi permasalahan umum apakah prestasi tim bola voli putri Kota Cirebon ini ada kaitanya dengan motivasi. menurut Harsono (Husdarta, 2011) "Betapa sempurna perkembangan fisik, teknik dan taktik atlet, apabila mentalnya tidak turut berkembang, prestasi tinggi tidak akan mungkin dicapai”.

Menurut Ashel (Komarudin, 2013), motivasi berasal dari bahasa latin “movere” yang berarti yang menggerakkan. Banyak definisi mengenai motivasi, Kompri (2016) menjelaskan bahwa: "Motivasi dapat diartikan sebagai kekuatan (energi) seseorang yang dapat 
menimbulkan tingkat persistensi dan antusiasmenya dalam melaksanakan suatu kegiatan, baik yang bersumber dari dalam diri individu itu sendiri (motivasi intrinsik) maupun dari luar individu (motivasi ekstrinsik)." Maka motivasi dapat didefinisikan sebagai dorongan yang berasal dari dalam atau dari luar diri individu untuk melakukan suatu aktivitas yang bisa menjamin kelangsungan aktivitas tersebut, serta dapat menentukan arah, haluan dan besaran upaya yang dikerahkan untuk melakukan aktivitas sehingga dapat mencapai tujuan yang telah ditetapkan. Motivasi dilihat dari fungsinya dibagi menjadi dua yaitu motivasi intrinsik dan motivasi ekstrinsik.

Teori motivasi Mc. Clelland memfokuskan pada tiga motivasi yaitu: “a) motivasi prestasi, b) motivasi afiliasi dan c) motivasi kekuasaan." Motivasi berprestasi merupakan suatu hal yang sangat penting dalamproses latihan dan pembelajaran di sekolah. Setidaknya para guru atau pelatih harus memiliki motivasi berprestasi untuk meningkatkan ke gairahan dalam pelaksanaan proses latihan dan belajar mengajar di sekolah. Tanpa motivasi berprestasi sukar bagi guru atau pelatih untuk mengembangkan dirinya selama proses latihan dan belajar. Sebagaimana Mc. Clelland (Husdarta, 2015) memberikan batasan motivasi prestasi (achievement motivation) sebagai berikut. Dorongan dalam diri untuk mengatasi segala tantangan dan hambatan dalam upaya mencapai tujuan. Orang yang memiliki dorongan ini berkembang dan tumbuh, serta keinginan menelusuri tangga keberhasilan. Penyelesaian sesuatu merupakan hal yang penting demi penyelesaian itu sendiri, tidak untuk imbalan yang mengatasinya.

Motivasi terbagi menjadi dua yaitu motivasi intrinsic dan motivasi ekstrinsik Komarudin (2013) menjelaskan bahwa: "Motivasi intrinsik sangat menentukan atlet untuk memutuskan dirinya untuk terus berpartisipasi dalam olahraga yang digelutinya. Bagi atlet yang memiliki motivasi intrinsik aktivitasnya dilakukan secara sukarela, penuh kesenangan dan kepuasaan, sehingga atlet merasa kompeten dengan apa yang dilakukannya.” Menurut Robert dan Daniel (Wijaya, 2016) menjelaskan ada tiga faktor dari motivasi instrinsik yang meliputi: Pengetahuan, Pencapaian dan Stimulasi.

Komarudin (2013) menjelaskan bahwa: "Motivasi ekstrinsik adalah motivasi yang timbul karena adanya faktor luar yang mempengaruhi dirinya." Faktor eksternal dapat mempengaruhi penampilan atau tingkah laku seseorang, yaitu menentukan apakah seseorang akan menampilkan sikap gigih dan tidak cepat putus asa dalam mencapai tujuannya. Menurut Robert dan Daniel (Wijaya, 2016), ada lima tipe motivasi ekstrinsik meliputi: Regulasi terpadu, RegulasiTeratur, Regulasi terpaksa dan Regulasi eksternal. 
Secara empiris, motivasi berprestasi atlet bola voli putri Kota Cirebon yang dibina melalui latihan saat ini masih terbilang rendah. Seyogianya, setelah dilakukan pembinaan latiahan selama 4 bulan tentunya akan menghasilkan peningkatan prestasi . akan tetapi, dalam kenyataanya tim bola voli putri Kota Cirebon tidak berhasil untuk meningkatkan prestasimya. Berdasarkan observasi yang dilakukan oleh peneliti terhadap pelatih dan atlet dari hasil Porda tahun 2018. Menurunya motivasi atlet bola voli putri Kota Cirebon disebabkan oleh faktorfaktor yang berasal dari dalam diri atlet (instrinsik atau internal) dan dari luar diri atlet (ekstrinsik atau eksternal) diantaranya atlet merasa tidak percaya diri ketika bertemu tim yang lebih kuat tim tersebut adalah tim yang pada saat porda tahun 2014 berhasil menjadi juara yaitu Kota Bandung dan Kabupaten Bandung, kurangnya dukungan dan support yang didapat oleh tim bola voli kota Cirebon dari segi penonton, terbebani oleh target yang diberikan pelatih kepada atlet

Berdasarkan penjelasan diatas, yang melatar belakangi penelitian ini bahwa ada faktor motivasi intrinsik dan ekstrinsik yang mempengaruhi prestasi tim bola voli putri Kota Cirebon. Oleh karena itu peneliti ingin mencari tahu faktor motivasi yang dominan apakah intrinsik atau ekstrinsik pada tim bola voli putri Kota Cirebon. Maka penelitian ini berjudul "Studi Terhadap Motivasi Berprestasi Tim Bola Voli Putri Kota Cirebon Pada Porda Tahun 2018”.

\section{Metode Penelitian}

Jenis penelitian yang digunakan dalam penelitian ini adalah deskriptif kuantitatif dengan metode survey.Variabel dalam penelitian ini adalah variabel tunggal karena hanya ada satu variabel yaitu faktor yang mempengaruhi motivasi berprestasi. Populasi dalampenelitian ini adalah atlet-atlet tim bola voli putri porda tahun 2018 yang berjumlah 12 orang. Sampel dalam penelitian ini adalah seluruh atlet bola voli putri Kota Cirebon yang berjumlah 12 orang tersebut. Pengumpulan data dalam penelitian ini adalah menggunakan teknik angket/kuisioner. Pengumpulan data dalam penelitian ini menggunakan bentuk skala likert.

Berdasarkan hasil pengujian validitas item dengan menggunakan rumus product moment, dapat diketahui hasil dari 28 item yang diajukan terhadap 12 responden diperoleh hasil semua item valid. Hasil uji coba reliabilitas dengan menggunakan rumus alpha terdapat 12 responden, skala motivasi dinyatakan reliabilitas instrumen adalah 0,763 . Jadi $0,763>0,576$ untuk itu karena harga reliabilitas tesnya lebih besar dari pada $\mathbf{r}_{\text {tabel }}$ dapat disimpulkan bahwa angket tersebut layak untuk digunakan atau reliabel. Untuk menganalisis data pada penelitian ini, peneliti menggunakan analisis deskriptif presentase. 


\section{Hasil dan Pembahasan}

Penelitian ini bertujuan untuk mengetahui apakah faktor motivasi intrinsic atau ekstrinsik yang dominan dalam motivasi berprestasi tim bola voli putri Kota Cirebon pada Porda tahun 2018 . Adapun hasilnya dapat digambarkan melalui table dan diagram dibawah ini.

Tabel 1. Paparan hasil penelitian motivasi berprestasi

\begin{tabular}{|c|c|c|c|c|c|c|c|}
\hline \multirow[b]{2}{*}{ No } & \multirow[b]{2}{*}{ Dimensi/ Indikator } & \multirow{2}{*}{$\begin{array}{c}\text { Paparan skor } \\
\text { maksimal } 12 \\
\text { responden }\end{array}$} & \multicolumn{2}{|c|}{ Pernyataan } & \multicolumn{2}{|c|}{ Persentase } & \multirow{2}{*}{$\begin{array}{l}\text { Persentase } \\
\text { Keseluruhan }\end{array}$} \\
\hline & & & + & - & + & - & \\
\hline 1 & Motivasi Intrinsik & 562 & 279 & 283 & 49.64 & 50.36 & $90 \%$ \\
\hline 2 & Motivasi Elkstrinsik & 579 & 284 & 295 & 49.05 & 50.95 & $75 \%$ \\
\hline
\end{tabular}

Sumber:-Data kuesioner yang diolah, 2018

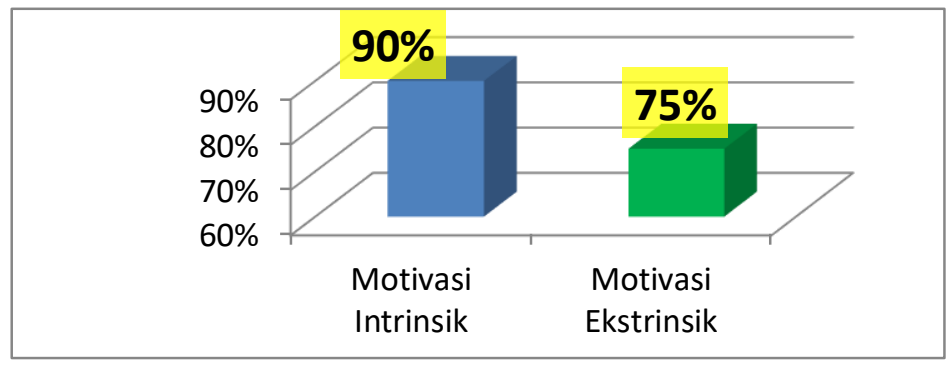

Diagram 1

Persentase Motivasi Intrinsik dan Ekstrinsik

Berdasarkan hasil deskriptif presentase diketahui bahwa faktor dominan pada motivasi berprestasi tim bola voli putri kota Cirebon adalah motivasi intrinsic dengan presentase sebesar 90\% sedangkan motivasi ekstrinsik hanya $75 \%$. dapat disimpulkan bahwa faktor dominan dalam motivasi berprestasi tim bola voli putri Kota Cirebon adalah motivasi intrinsik karena diantara kedua motivasi ini yang lebih efektif, dari pandangan beberapa ahli Gunarsa, Nugraha, Singer (Husdarta, 2011) menyatakan bahwa "sebenarnya motivasi intrinsik lebih efektif dari pada motivasi ekstrinsik". Namun demikian dalam struktur realitanya kedua motivasi tersebut tidak dapt berdiri sendiri-sendiri melainkan bersama-sama menurut Halliwell (Muskanan,2015) menyatakan bahwa "sebenarnya motivasi dasar tingkah laku individu dalam olahraga adalah motivasi intrinsik, namun selalu ditambah dengan motivasi ekstrinsik. Dorongan ekstrinsik dapat meningkatkan motivasi intrinsik."

Tabel 2. Paparan hasil tiap sub indikator motivasi intrinsik

\begin{tabular}{|c|c|c|}
\hline \multicolumn{3}{|c|}{ Motivasi Intrinsik } \\
\hline Pengetahuam & Pencapaiam & Stimulasi \\
\hline 189 & $\mathbb{1} \mathbf{g}$ & $1 \mathrm{86}$ \\
\hline 93.44 & 97.4 & 96.83 \\
\hline
\end{tabular}




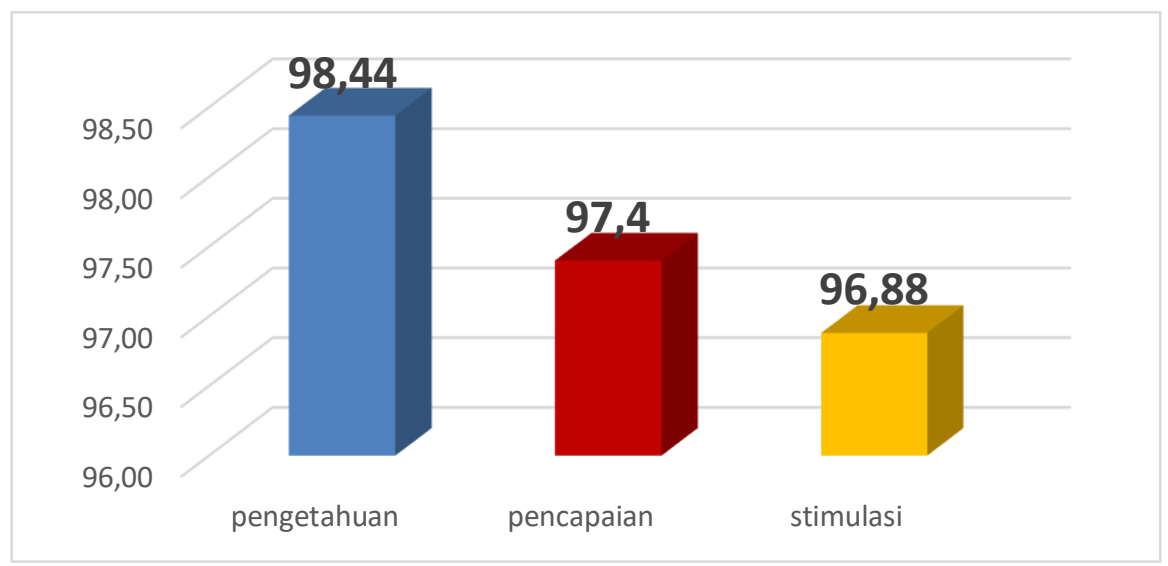

\section{Diagram 2}

Indikator Motivasi Intrinsik

Pengetahuan, Pencapaian dan Stimulasi

Berdasarkan hasil deskriptif presentase, bahwa semua indikator berpengaruh terhadap motivasi berprestasi, adapun sub indikator dari masing-masing indikator motivasi intrinsik yaitu pengetahuan, pencapaian dan stimulasi.

Berdasarkan penghitungan tiap sub indikator dari motivasi intrisnik yang meliputi Pengetahuan seperti kontrol diri, disiplin dan mandiri sebesar 189 dengan presentase 98,44\%, Pencapaian seperti kemampuan dan percaya diri sebesar 187 dengan presentase 97,4\% pada penelitian ini pencapaian seperti kemampuan dan percaya diri hanya berbeda sekian persen dengan pengetahuan, ini ditunjukan Farradina (2012) "bahwa terdapat hubungan positif yang sangat signifikan antara motivasi dengan kepercayaan diri atlet dalam menghadapi PON-18 tahun 2012.”

Stimulasi seperti konsentrasi dan tujuan sebesar 186 dengan presentase 96,88\%, pada penelitian ini aspek stimulasi seperti konsentrasi dan tujuan hanya berbeda sekian persen dengan pengetahuan ini ditujukan Gustian (2016) "bahwa konsentrasi memiliki peran penting pada aktifitas olahraga, menurunnya konsentrasi atlet maka berdampak negatif."

Pengetahuan seperti kontrol diri, disiplin dan mandiri sebesar 189 dengan presentase 98,44\%, dari hasil paparan diatas maka dapat disimpulkan salah satu faktor dari motivasi berprestasi tim bola voli Kota Cirebon dalam indikator mativasi intrinsik adalah Pengetahuan meliputi kontrol diri, displin dan mandiri dibuktikan oleh Muskanan (2015)", kompetensi merupakan variabel yang paling dominan berpengaruh dan mempunyai hubungan yang kuat pengaruhnya terhadap prestasi atlet analisis motivasi berprestasi atlet pusat pendidikan dan olahraga pelajar (PPLP) Provinsi Nusa Tenggara Timur". Hal ini juga diungkapkan oleh Husdarta (2011) ciri-ciri atlet yang menginternalisasi motivasi intrinsik antara lain : 1) berorientasi pada kepuasan dalam dirinya, 2) biasanya rajin dan tekun, bekerja keras, teratur 
dan disiplin dalam menjalani latihan, 3) tidak suka bergantung pada orang lain, 4) memiliki karakteristik kepribadian yang positif, matang, jujur dan sportif, 5) aktifitas lebih permanen.

Tabel 3. Paparanhasil tiap sub indikator motivasi ekstrinsik

\begin{tabular}{|c|c|c|c|}
\hline \multicolumn{4}{|c|}{ Motivasi Elstrinsik } \\
\hline Penghargaan & Sarana & Prasarana & Perhatian \\
\hline 150 & 143 & 154 & 132 \\
\hline 78.13 & 74.48 & 80.21 & 68.75 \\
\hline
\end{tabular}

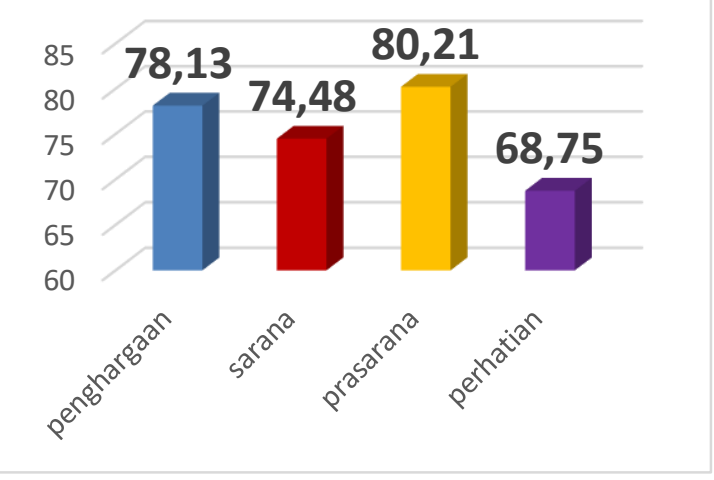

Diagram 3

Indikator Motivasi Ekstrisik

Perngharagaan, Sarana, Prasarana dan Perhatian

Berdasarkan hasil deskriptif presentase, bahwa semua indikator berpengaruh terhadap motivasi berprestasi, adapun sub indikator dari masing-masing indikator motivasi ekstrinsik yaitu Penghargaan, sarana, prasarana dan perhatian.

Berdasarkan penghitungan tiap sub indikator dari motivasi ekstrinsik yang meliputi yaitu penghargaan seperti hadiah dan kedudukan sebesar 150 dengan presentase $78,13 \%$ penghargaan mendapat persentase yang rendah dari pada prasarana artinya bagi tim bola voli putri Kota Cirebon penghargaan merupakan salah satu faktor dalam motivasi berprestasi Juwita (2009) "bahwa penghargaan dari pemerintah bagi atlet berupa uang, mendali, piagam mampu memacu para atlet untuk lebih berprestasi”.

Sarana seperti tempat, letak geografis dan venue sebesar 143 dengan presentase $74,48 \%$ sarana tempat, letak geografis dan venue berpengaruh terhadap motivasi berprestasi tim bola voli putri Kota Cirebon Pramudipta (2017) "suasa pertandingan atlet mempengaruhi penampilan saat pertandingan seperti sorak soray dan komentar negatif penonton membuat motivasi berprestasi mereka turun akhirnya menghambat atlet tampil optimal".

Perhatian seperti sosmed dan pujian sebesar 132 dengan presentase 68,75\% perhatian pada penelitian ini memiliki nilai yang lebih rendah walaupun begitu perhatian seperti sosmed 
dan pujian merupakan faktor yang mempengaruhi prestasi Nurjalia (2018) menyatakan bahwa: "sosial media sangat berpengaruh terhadap prestasi".

Dari hasil tersebut maka dapat disimpulkan motivasi berprestasi tim bola voli Kota Cirebon dalam indikator motivasi ekstrinsik yang paling dominan adalah Prasarana seperti alat latihan sebesar 154 dengan presentase 80,21\% seperti alat latihan hal ini juga ditunjukan dengan hasil penelitian Setyawati (2014) menyatakan bahwa: "faktor situasi seperti lingkung latihan dan alat latihan mendapat presentase yang paling tinggi sebesar 92\%”. Hal ini juga dibuktikan Muskanan (2015:110) yang menyatakan bahwa "dari hasil kuantitatif pada PPLP NTT menggambarkan bahwa ketersediaan sarana dan prasarana secara signifikan dapat menunjang proses proses pembinaan dan kepelatihan yang berlangsung dan memotivasi atlet untuk meningkatkan prestasi dari prestasi sebelumnya."

\section{Kesimpulan}

Berdasarkan hasil dari penelitian yang telah dilakukan, dapat disimpulakan bahwa nilai ratarata dari motivasi berprestasi 95,08 dengan presentase 84\% dikategorikan "Sangat Tinggi", adapun hasil dari tiap indikatornya adalah motivasi intrinsik nilai rata-rata 46,83 presentase 90\% dengan kategori "Sangat Tinggi" sedangkan motivasi ekstrinsik nilai rata-rata 48,25 presentase $75 \%$ kategori "Tinggi", ini menunjukan bahwa faktor dominan dalam motivasi berprestasi tim bola voli putri Kota Cirebon pada porda tahun 2018 adalah indicator motivasi instrinsik.

Adapun motivasi ini muncul dipengaruhi beberapa indikator pendukung antara lain: motivasi instrinsik, pengetahuan sebesar 189 dengan tingkat persentase sebesar 98,44\%, dikategorikan "Sangat Tinggi”. Pencapaian sebesar 187 dengan tingkat persentase sebesar 97,4 \%, dikategorikan "Sangat Tinggi”. Stimulasi sebesar 186 dengan tingkat persentase sebesar 96,88 \%, dikatagorikan "Sangat Tinggi” disimpulkan bahwa dalam aspek motivasi instrinsik indikator pengetahuan memiliki nilai yang lebih tinggi atau memiliki peranan penting dalam motivasi berprestasi tim bola voli putri Kota Cirebon. Motivasi ekstrinsik, penghargaan sebesar 150 dengan tingkat persentase sebesar 78,13 \%, dikatagorikan "Sangat Tinggi”. Sarana sebesar sebesar 143 dengan tingkat persentase sebesar 74,48 \%, dikatagorikan "Tinggi". Prasarana adalah sebesar sebesar 154 dengan tingkat persentase sebesar 80,21\%, dikatagorikan "Sangat Tinggi”. Perhatian adalah sebesar sebesar 132 dengan tingkat persentase sebesar 68,75\%, dikatagorikan "Tinggi" hal ini dapat disimpulkan bahwa dari hasil penelitian yang telah dilakukan bahwa dalam aspek motivasi ekstrisnik indikator prasarana memiliki nilai yang lebih 
tinggi atau memiliki peranan penting dalam motivasi berprestasi tim bola voli putri Kota Cirebon.

\section{Daftar Pustaka}

Arikunto. (2010). Prosedur Penelitian Suatu Pendekatan Praktek. Jakarta: Rineka Cipta.

Badriah, D. L. (2012). Metodologi Penelitian. Bandung: Multazam.

Depdiknas. (2000). Kamus Besar Bahasa Indonesia. Jakarta: Balaikota.

Faisal, I. A. (2008). Pembinaan Prestasi Di Sekolah Bola Voli Bima Loka Kabupaten Jember Pada Usia 16-18 Tahun. Jurnal. Surabaya. Fakultas Ilmu Keolahragaan. Universitas Negeri Surabaya.

Farradinna, S. (2012). Motivasi Berprestasi Atlet Muda Dalam Menghadapi Pekan Olahraga Nasional Tahun 2012 Ditinjau Dari Kepercayaan Diri. Jurnal. Pekanbaru: Fakultas Psikologi Universitas Islam Riau Pekanbaru.

Firmansyah, D. (2018). Sosiologi Olahraga. Malang: Wineka Media.

Gustian, U. (2016). Pentingnya Perhatian dan Konsentrasi Dalam Menunjang Penampilan Atlet. Jurnal. Padang: Fakultas Ilmu Keolahragaan Universitas Negeri Padang.

Husdarta. (2011). Psikologi Olahraga. Bandung: Alfa Beta.

- (2015). Manajemen Pendidikan Jasmani. Bandung: Alfa Beta.

Juwita, S. (2009). Gambaran Motivasi Berprestasi Pada Perempuan Tenis Kursi Roda. Jurnal. Jakarta: Fakultas psikologi. Universitas Kristen Krida Wacana.

Komarudin. (2013). Psikologi Olahraga Latihan Mental Dalam Olahraga Kompetitif. Bandung: Rosdakarya.

Kompri. (2016). Motivasi Pembelajaran Perspektif Guru dan Siswa. Bandung: Rosdakarya.

Muskanan, K. (2015). Analisis Motivasi Berprestasi Atlet Pusat Pendidikan dan Latihan Olahraga Pelajar (PPLP) Provinsi Nusa Tenggara Timur. Jurnal. Kupang: Program Pascasarjana Universitas Nusa Cendana.

Nazir, M. (2013). Metode Penelitian. Jakarta: Ghalia Indonesia.

Ngatiyono. (2010). Mari Sehat Bergembira Pendidikan Jasmani, Olahraga dan Kesehatan Untuk SD/MI kelas IV. KEMENDIKBUD.

Nurjalia. (2018). Pengaruh Sosial Media Terhadap Prestasi Akademik Mahasiswa Program Studi Pendidika Teknologi Informasi. Jurnal. Banda Aceh: Fakultas Tarbiyah dan Keguruan Universitas Islam Negeri Ar-ranty.

Rahayu, M. (2015). Hubungan Antara Goal-Setting dan Motivasi Berprestasi dengan Prestasi Atlet Renang. Jurnal. Surabaya: FIP Psikologi UNESA.

Sanjaya. (2015). Motivasi Dalam Mengikuti Kegiatan Ekstrakurikuler Sepak Bola Pada Siswa SMP Negeri 1 Sukaharjo. Pringsewu: Skripsi. Program Studi Strata 1 Universitas Lampung.

Setyawati, H. (2014). Survei Motivasi Prestasi Atlet Klub Bulutangkis Pendowo Semarang Tahun 2014. Jurnal. Semarang: Universitas Negeri Semarang.

Subroto, T. (2010). Permainan Bola Voli. FPOK: Universitas Pendidikan Indonesia.

Sugiyono. (2017). Metode Penelitian Pendidikan, Pendekatan Kuantitatif Kualitatif dan $R \& D$. Bandung: ALFABETA,cv.

Sukmadinata. (2010). Metode Penelitian Pendidikan. UPI Bandung: Remaja Rosdakarya

Susanto, A. (2018). Bimbingan dan Konseling di Sekolah, Komsep, Teori, dan Aplikasinya. Jakarta: Prenadamedia Group.

Wijaya, N. (2016). Motivasi Atlet Mengikuti Latihan Bola Voli Yuso Sleman Putri Ditinjau Dari Motif Berprestasi. Skripsi. Yogyakarta: FIK UNY.

Yaniawati, I. 2017. Metode Penelitian Kuantitatif, Kualitatif, dan Campuran untuk Manajgemen, Pembangunan, dan Pendidikan. Bandung: PT Refika Aditama. 